\title{
Hva skulle Tidsskriftet gjort uten sosiale medier?
}

\author{
Spørsmålet er egentlig retorisk. Og svaret ligger delvis gjemt i Google Analytics. Analyseverktøyet \\ som forteller det meste vi trenger å vite om våre leseres bruk av Tidsskriftets nettsider.
}

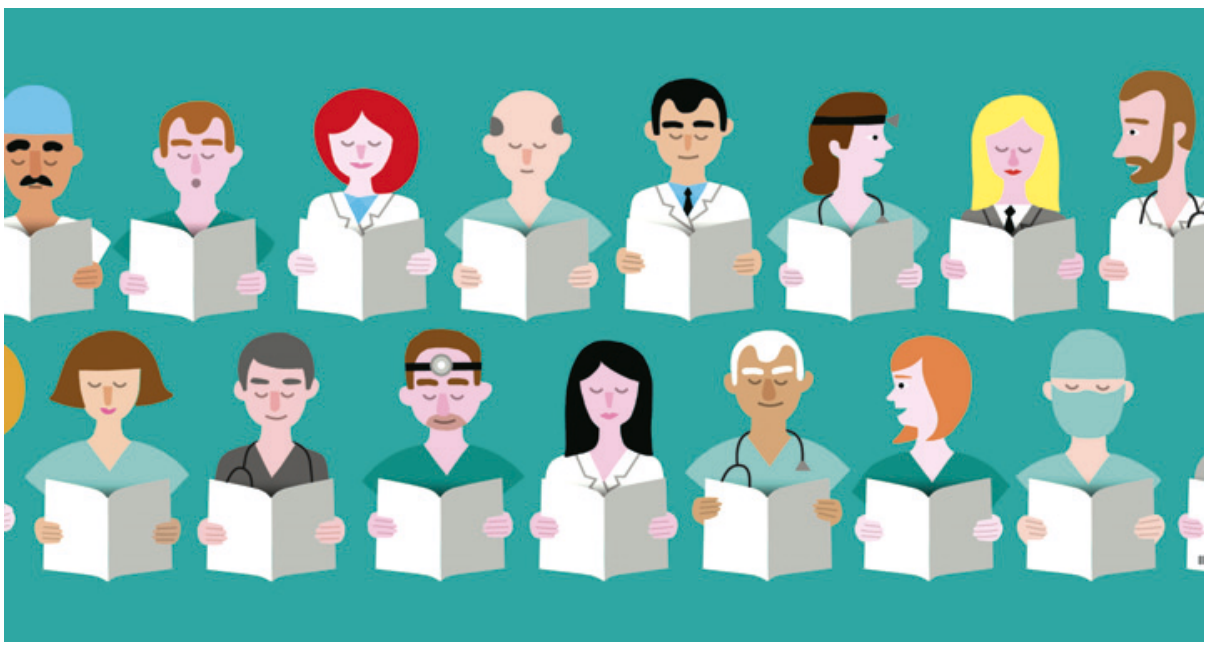

Illustrasjon Kristin Roskifte

Halvårsoppsummeringen av trafikken til våre nettsider viser en tendens vi har sett lenge: Mengden trafikk som kommer fra sosiale medier er økende. Og da er det særlig de sosiale nettverkene Facebook og Twitter som gjør seg gjeldende, med et solid forsprang for Facebook.

Ser vi derimot litt bak besøkstallene, for eksempel på hvor lang tid folk blir værende på siden, ser vi at de som besøker oss fra Twitter bruker lengre tid på siden. Med over ett minutts soleklare forskjell i forhold til Facebook, kan man påstå at tvitrere er mer interesserte lesere. Det er kanskje ekstra gledelig å se, når vi samtidig kan notere at selv om det faktiske antall lesere som kommer fra Twitter er noe lavere, er det den kilden som har hatt brattest økning.

Det er også forskjell i trafikken fra Facebook og Twitter når det kommer til type artikkel det klikkes på. Mens våre lesere på Facebook i all hovedsak liker mykere sjangre, som kuriosa, intervju, gjesteskribent og personlige historier, er tvitrerne vel så opptatt av medisinske nyheter og tungt fagstoff. Dette gjelder også tvitrere uten medisinsk bakgrunn. Også debattstoffet går noe bedre på Twitter.

Et annet - og kanskje vel så interessant funn fremkom under sammenlikningen mellom tidsskriftet.no og bloggen: blogg.tidsskriftet.no.

Tidsskriftet.no får i all hovedsak trafikk fra søkemotorer. Et logisk funn ettersom siden også fungerer som et stort kunnskapsarkiv. Men for bloggen er det annerledes. Her er det nesten utelukkende sosiale medier som er trafikkdriver. Dette bekrefter teorien om at sosiale medier snakker bra sammen, og forsterker hverandre.

Enda mer overraskende enn ulikheten mellom hovedsiden og bloggen, var det å finne at det var en forsvinnende liten andel av søkene som traff de nyeste artiklene. Det medisinske nyhetsstoffet er kanskje ikke like avhengig av sosiale medier som debattstoffet på bloggen, men forskjellen er mye mindre enn man kanskje skulle tro. Vi våger derfor å si at alt innhold på nett er avhengig av den trafikkdriveren sosiale medier har blitt.

Det være seg om delingene, og den påfølgende oppmerksomheten, er skapt av oss selv eller om det er våre lesere som videreformidler vårt stoff.

Vi kan altså gi oss selv klapp på skulderen for å følge med i den digitale timen. Sistnevnte noe vi også fikk pris for under årets Fagpresseprisene.

Viktigere er det imidlertid å se på hva disse tallene kan fortelle om fremtiden. Den er som «alle» vet digital. Og også for medisinske nyheters del; sosial.

Skiller man derimot mellom nyheter og debattstoff $i$ kortformat, og de lengre originalartiklene og oversiktsartiklene, er det ikke like entydig. I hvert fall ikke når det
Aslaug Olette Klausen

aslaug.olette.klausen@legeforeningen.no Webkommunikatøri Tidsskrift for Den norske legeforening. Medieviter og musikkjournalist.

\section{PUBLISERT I BLOGGEN \\ เে 1.8. 2013}

\section{«Sosiale medier snakker bra sammen»}

gjelder hvilke sosiale medier man skal velge å vektlegge for (egen)deling.

Det kan se ut til at alt fungerer, og trolig vi fortsette å gjøre det bedre, på Twitter. Facebook utmerker seg som nevnt på saker av lettere tilgjengelighet. Disse delingene kan til og med være av lange artikler. Er det derimot artikler med utpreget teknisk og faglig karakter ser det ikke ut til å gjøre noen egentlig forskjell om det er langt eller kort. Responsen er uansett lunknere.

Men ettersom det alltid er bunnlinjen $i$ antall treff som teller mest, vil det å overlate det koselige til Facebook og det mer faglige til Twitter, foreløpig være noe for en fjernere fremtid. Men tendensen er her allerede.

I all denne hyllesten av mulighetene på nett, skal det imidlertid ikke underkjennes at tradisjonelle medier heller ikke er til å kimse av. Et oppslag på TV2.no om vidundermiddelet Naltrekson har gjort vår artikkel om medikamentet til årets nest mest leste. Mest lest er imidlertid kronikken: «Ta faget tilbake!» Den fikk til tross for tradisjonelle medieoppslag over halvparten av visningene fra sosiale medier, og $86 \%$ av den sosiale trafikken kom fra Facebook...

Kommentarer til og diskusjoner om innlegget finner du på blogg.tidsskriftet.no Vil du blogge, ta kontakt. 